\title{
The Management Perception Toward the Concept and Challenges Facing the Traditional Food in the Hotel sector: A research in Luxor city
}

Ali Elgably Labibe Mohammed Abd El-Wahab Morsy Omar Qoura

Faculty of Tourism and Hotels- Fayoum University

\begin{abstract}
Traditional foods are an expression of culture, history, and lifestyle of the local people, traditional foods are also often related to local foods referring to the used of specific local ingredients in local production which highly involve the knowledge and expertise of local people. The aim of this research is to examine the factors affect on the spread of traditional food in the tourism areas at Luxor and identify the benefits and challenges of using traditional foods in Luxor hotels One hundred seventy questionnaires were distributed to food \& beverage managers and supervisors in five-star hotels in Luxor, one hundred fifty were fully completed and returned with a response rate of $88.2 \%$. The main findings indicated that the majority of respondent give the right definition of traditional food and the respondents indicated they serve to the guest traditional food like Koushary - Kebab Halla - Moulkhia - Rise Khalta - Tamia - Fool Medamis Weka - Aish Shames - Sheesh Kebab - Besara - Thikhna - Fata The researcher suggests taking into consideration the important contribution of foods and beverages in the tourist activity, incorporation of some of the traditional food items is a good idea for the hospitality industry in Egypt.
\end{abstract}

Keywords: Traditional Food, Food Tourism, Gastronomy Tourism, Sense of Place, Marketing Share, Attraction Tool, Food Flavor.

\section{Introduction}

In recent years, food tourism has grown considerably and has become one of the most dynamic and creative segments of the tourism, both destinations and tourism companies are aware of the importance of gastronomy in order to diversify tourism and stimulate local, regional and national economic development, furthermore, food tourism includes in its discourse ethical and sustainable values based on the territory, the landscape, the sea, local culture, local products, authenticity, which is something it has in common with current trends of cultural consumption(World tourism organization,2012). Changes in the ways in which food was obtained in ancient times transformed the status of food from a basic survival necessity to a commodity associated with wealth, celebration, rituals, and leisure (Tannahill, 2002). At the same time, the exchange of food stuffs over long distances and the transfer of food-related ideas and knowledge across cultures assisted in the construction of cultural identities and social hierarchies Pilcher, (2006). These historical events were interpreted by (Boniface, 2003).

\section{The significance of the research}

The scientific importance of the research is to identify the factors that affect the spread of traditional food in five-star hotels, specifically in the province of Luxor.

\section{Aim and Objectives of The study}

The primary aim of this study is to study the factors on the spread of traditional food in the Luxor city, To achieve this, the main objective divided in to sub-objectives

- Identify the extent traditional foods are used in Luxor five star hotels

- Explain the current role of traditional food in hotels

- Identify the benefits and challenges of using traditional foods in Luxor hotels. 


\section{Statement of the Problem}

Food and dining is typically lumped together with accommodations in an assemblage of tourism statistics that is pushing the researcher to do the study furthermore there is a need for conceptually based research set in a positivistic paradigm within the framework of social sciences that empirically examines traditional food (Selwood, 2003)

\section{Questions of the Study}

What are the effective factors helping the spread of traditional food?

What is the concept of traditional food?

What is the status of serving the traditional food in five-star hotels in Luxor?

Are the heads of department and supervisors of food and beverage know the benefits of traditional food?

What are the challenges facing five-star hotels to serving traditional food?

\section{Review of literature \\ Food tourism}

According to Jalis et al, (2014) travelling to a tourism destination can be made more exciting by experiencing the local cuisine, the variety of cooking methods and colorful ingredients blend together in a hot wok to create signature dishes of particular cuisines, Nevertheless, a cuisine needs to be clearly defined by definite individual characteristics so it is recognised. UNWTO, (2012) pointed out that travelers are more experienced, have more disposable income and more leisure time to travel, and thus tourism allows them to escape the daily routine of their usual environment and immerse themselves in a world of freedom and novelty.

According to Gall (2018), traditional food products represent an important element of culture, identity, and heritage and are characterized by both historical and geographical dimensions, the increasing attention is shown in the past 25 years by academics, politicians, and food system actors, and their recognition through geographical indications, stems from their implications on economic, juridical, political and social grounds.

\section{Definition of traditional heritage and local food}

According to Verbeke, (2011) and Vanhonacker et al. (2008) "traditional foods product is a product frequently consumed by or associated with specific celebrations and/or seasons; normally transmitted from one generation to another; made accurately (made with care) in a specific way according to the gastronomic heritage; with little or no processing/manipulation; distinguished and known because of its sensory properties and associated with a certain local area, region or country."

Trichopoulou et al, (2007) argued that traditional foods are an expression of culture, history, and lifestyle of local people. Traditional foods are also often related to local foods referring to the users of specific local ingredients in local production which highly involve the knowledge and expertise of local people.

\section{Sense of Place}

Authenticity is an attribute that could be specifically relevant to ethnic restaurants. It refers to whether the food and environment reflect the genuine or ,reale taste and culture of the ethnic origin. Another attribute of restaurant experience, atmosphere, has been shown to be a powerful factor in customer satisfaction (Ebster and Guist, 2005, Liu and Jang, 2009). There is also a need to study traditional foods to enhance and improve our diet and at the same time bring the important elements of our cultural inheritance (Trichopoulou et al, 2006). 
Guerrero et al., (2009) stated that every ethnic group in this world has a diverse native, and each of them has their cultural practices, beliefs, and social norms. Each native possess to have their individuality as being expressive identity and integral component of culture and tradition,

The motivation for serving traditional food

Various studies have found that motivational factors affect tourist food consumption and local food is of primary importance for the overall satisfaction of a trip (Cetin \& Bilgihan, 2015). Fields, (2002) have suggested four motivational factors for tourists to consume local food; physical, cultural,

interpersonal and statue motivators. Kim et al., (2003) offer nine sub-factors when explaining motivational factor as; exciting experience, escape from routine, health concern, learning knowledge, authentic experience, togetherness, prestige, sensory appeal and physical in their model of local food consumption. The dimensions of tourists' food motivation have been categorized in two main categories as symbolic dimensions (learning the local culture, exciting experience, authenticity, prestige), and obligatory dimensions (health concern, physical need, etc.) (Mak et al., 2012). Tasting local food is claimed to be a pleasurable and exciting activity by Kivela and Crotts, (2006).

\section{Factors affecting the Traditional Foods}

Because of the increasing globalization and internationalization of the food market, many traditional foods are at risk of disappearing, the documentation of traditional foods and dishes is essential for sustaining traditional foods, which are an important part of cultural heritage. (Weichselbaum et al., 2009) In fact, food and wine tourism have seen a growing demand in recent years. Today, we witness an increasing number of travelers interested in culinary destinations, a trend that seems to consolidate year after year, The values of society have changed and, today, products like wine and food are associated with leisure and relaxation, and not merely basic necessities, food is now a cultural element, an experience similar to visiting a museum or going to a music concert. (UNWTO, 2012) indicated that eating is a basic need of human nature, every tourist eats local food when travelling away from home. Taste, looks, the scent of the food and the authenticity of the place are sensory issues perceived by five senses and can be considered as physical motivators (Fields, 2002). On the other hand, Telfer \& Wall (2000) argued that some tourists might prefer the kind of food they eat back in their origin. Quan \& Wang (2004) indicated that tourists may stay in western hotel chains in Asia in order to avoid local tastes but if they are in search of novelty they may choose to eat local food as well. past experience also affects food choice at a destination. The earlier experiences of tourists about food can influence future visits to the destinations. Experienced tourists might be more willing to try different food alternatives compared to first-time visitors (Ryu \& Jang, 2006).

\section{Research Methods \\ Results and discussions}

Table (1): Response Rate the Questionnaire Managers

\begin{tabular}{|c|c|}
\hline five-star hotels & Category \\
\hline 170 & Number \\
\hline 150 & Number \\
\hline $88.2 \%$ & Response rate \\
\hline
\end{tabular}

One hundred seventy questionnaires were distributed to food \& beverage manager and supervisors in five-star hotels in Luxor one hundred fifty were fully completed and returned with a response rate $88.2 \%$ 
Table (2): The Respondents' Awareness of the Concept of Traditional Food

\begin{tabular}{|c|c|c|c|c|c|c|c|c|}
\hline \multirow[t]{2}{*}{ The concept of traditional food } & \multicolumn{5}{|c|}{ Five points Likert Scale } & \multirow[t]{2}{*}{$\mathrm{M}$} & \multirow[t]{2}{*}{ Std } & \multirow[t]{2}{*}{$P$} \\
\hline & 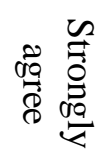 & 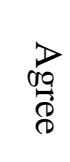 & 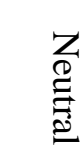 & 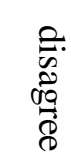 & 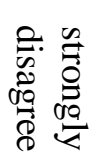 & & & \\
\hline $\begin{array}{l}\text { 1-those food that prepared from } \\
\text { origin or local's ingredients }\end{array}$ & 25 & 77 & 12 & 6 & 30 & 3.41 & 1.366 & 68.1 \\
\hline $\begin{array}{l}\text { 2.its food items that the citizens and } \\
\text { majority are using it more than } \\
\text { other food items because of the } \\
\text { abundance of sources and easily } \\
\text { prepared }\end{array}$ & 51 & 42 & 6 & 45 & 6 & 3.58 & 1.332 & 71.6 \\
\hline $\begin{array}{l}\text { 3. Include plants herbs vegetables } \\
\text { and fruits which are locally grown } \\
\text { and interference in the preparation } \\
\text { of the daily meals }\end{array}$ & 34 & 68 & 18 & 20 & 10 & 3.64 & 1.166 & 72.8 \\
\hline $\begin{array}{l}\text { 4. Are those the food be the origin } \\
\text { and prepared from local crops and } \\
\text { extends from heritage customs and } \\
\text { traditional where it is easy to } \\
\text { manufacture preparation and } \\
\text { sources are available }\end{array}$ & 128 & 16 & 3 & 3 & 0 & 4.79 & 0.571 & 95.8 \\
\hline
\end{tabular}

$\mathrm{S} . \mathrm{D}=$ standard deviation, $\mathrm{M}=$ mean, $\mathrm{P}=$ percentage

According to Table 2, the results showed that the concept varies among the respondent's and every respondent indicated the meaning of traditional food according to his own knowledge and his work experience. Respondents' views are categorized respectively according to the most spread concept as follow:

Are those the food be the origin and prepared from local crops and extends from heritage customs and traditional where it is easy to manufacture preparation and sources are available (95.87\% of respondents)

Include plants and herbs and vegetables and fruits which are locally grown and interference in the preparation of the daily meal ( $72.8 \%$ of respondents)

it's food items that the citizens and majority are using it more than other food items because of the abundance of sources and easily prepared (71.6\% of respondents)

that food prepared from origin or local's components (68.13\% of respondents)

The results indicated that $95.87 \%$ of respondent give the right definition of traditional food and this agrees with by that there is no specific legal definition heritage food.

Table (3) The usage of Traditional Food in the hotels' menus

\begin{tabular}{|c|c|c|c|}
\hline & & Frequency & Percent \\
\hline 1 & Yes & 144 & 96.0 \\
\hline 2 & No & 6 & 4.0 \\
\hline & Total & 150 & 100.0 \\
\hline
\end{tabular}

The results in table 3 showed that the majority (95\%) of the respondents agree that their hotels menu contains varieties of traditional food 
Table (4): The types of The Traditional Food provided in the investigated hotels Menu

\begin{tabular}{|c|c|c|c|}
\hline No & Categories & Frequency & Percent \\
\hline 1 & koushary & 90 & 62.5 \\
\hline 2 & Kebab halla & 124 & 86.11 \\
\hline 3 & moulkhia & 133 & 92.36 \\
\hline 4 & Rise khalta & 122 & 84.72 \\
\hline 5 & tamia & 98 & 68.06 \\
\hline 6 & Fool medamis & 111 & 77.08 \\
\hline 7 & weka & 132 & 91.67 \\
\hline 8 & Aish shamse & 111 & 77.08 \\
\hline 9 & Shiesh kebab & 125 & 86.81 \\
\hline 10 & besara & 97 & 67.36 \\
\hline 11 & Thikhna & 45 & 31.25 \\
\hline 12 & Fata & 91 & 63.19 \\
\hline
\end{tabular}

Concerning the benefits of traditional food the respondents indicated as showed in table (4) that the menu of their hotels continues these traditional food and also they serve to the guest and according to the table the percentage (moulkhia 92.36\% - weka 91.67\% - shiesh kebab $86.81 \%$ kebab halla $86.11 \%$ - rise khalta $84.72 \%$ - fool medamis $77.08 \%$ - aish shames $77.08 \%$ - tamia $68.06 \%$ - besara $67.36 \%$ - koushary $62.5 \%$ - fata $63.19 \%$ - thikhna $31.25 \%$. according and agree to the hotels menus

Table (5): The benefits of the Traditional Food usage

\begin{tabular}{|l|c|c|c|c|c|c|c|c|}
\hline \multicolumn{1}{|c|}{ Factors } & $\begin{array}{c}\text { strongly } \\
\text { agree }\end{array}$ & Agree & Neutral & disagree & $\begin{array}{c}\text { strongly } \\
\text { disagree }\end{array}$ & M & Std & P \\
\hline $\begin{array}{l}\text { 1-It is considered } \\
\text { an attraction tool }\end{array}$ & 28 & 89 & 18 & 12 & 3 & 3.85 & 0.888 & 76.93 \\
\hline $\begin{array}{l}\text { 2-Contributes to } \\
\text { increasing the } \\
\text { number of tourists }\end{array}$ & 18 & 43 & 51 & 34 & 4 & 3.25 & 1.023 & 64.93 \\
\hline $\begin{array}{l}\text { 3- Increases the } \\
\text { market share of } \\
\text { the hotel }\end{array}$ & 39 & 39 & 43 & 26 & 3 & 3.57 & 1.114 & 71.33 \\
\hline $\begin{array}{l}\text { 4--It helps to } \\
\text { identify people } \\
\text { customs and } \\
\text { cultures }\end{array}$ & 90 & 39 & 0 & 21 & 0 & 4.32 & 1.032 & 86.4 \\
\hline $\begin{array}{l}\text { 5-Encourages the } \\
\text { uptake of local } \\
\text { products }\end{array}$ & 67 & 34 & 25 & 6 & 18 & 3.84 & 1.356 & 76.8 \\
\hline $\begin{array}{l}\text { 6-Help to use local } \\
\text { agricultural } \\
\text { products }\end{array}$ & 68 & 49 & 27 & 6 & 0 & 4.19 & 0.872 & 83.87 \\
\hline $\begin{array}{l}\text { 7-Offers a new } \\
\text { hotel product }\end{array}$ & 50 & 44 & 41 & 12 & 3 & 3.84 & 1.043 & 76.8 \\
\hline & 360 & 337 & 205 & 117 & 31 & 3.83 & 1.073 & 76.69 \\
\hline
\end{tabular}

To identify the extent of the effect of traditional food positively the researcher put the factors on a Likert scale. as shown in table (5): The mean score of respondents was more than the value 3.83 from a Likert scale (1 strongly disagree, 2 disagree, 3 neutral, 4 agree and 5 strongly agree) for all factor, The result pointed out that It helps to identify peoples customs and cultures $86.4 \%$ 
Help to use local agricultural products $83.87 \%$-traditional food effect positively and It is considered an attraction tool $(76.93 \%)$ - Offers a new hotel product $76.8 \%$ Increases the market share of the hotel $71.33 \%$ - Contributes to increasing the number of tourists $64.93 \%$ and this result agree with Fathimath,(2009)(Tao\&Wall,2009) (Santich,2007) (Sharma,2005) Eastham(2003) (Hall and Sharples,2003) Jones and Jenkins(2002).

Table (6): The Most Important challenges that affects the ser of vice Traditional Food

\begin{tabular}{|l|c|c|c|c|c|c|c|c|}
\hline \multicolumn{1}{|c|}{ The concept } & $\begin{array}{c}\text { strongly } \\
\text { agree }\end{array}$ & agree & Neutral & disagree & $\begin{array}{c}\text { strongly } \\
\text { disagree }\end{array}$ & M & Std & P \\
\hline $\begin{array}{l}\text { 1-The guests does } \\
\text { not know about the } \\
\text { traditional food }\end{array}$ & 77 & 28 & 12 & 6 & 27 & 3.81 & 1.534 & 76.27 \\
\hline $\begin{array}{l}\text { 2-Consumers fear } \\
\text { the use of this type } \\
\text { of food }\end{array}$ & 65 & 34 & 15 & 29 & 7 & 3.81 & 1.304 & 76.13 \\
\hline $\begin{array}{l}\text { 3-Lack of good } \\
\text { marketing for these } \\
\text { food }\end{array}$ & 84 & 30 & 18 & 9 & 9 & 4.2 & 1.128 & 84.08 \\
\hline $\begin{array}{l}\text { 4-Globalization and } \\
\text { proliferation of fast } \\
\text { food }\end{array}$ & 85 & 19 & 28 & 9 & 9 & 4.08 & 1.24 & 81.6 \\
\hline $\begin{array}{l}\text { 5-Some customers } \\
\text { believe that these } \\
\text { food are not } \\
\text { healthy }\end{array}$ & 56 & 35 & 21 & 22 & 16 & 3.62 & 1.389 & 72.4 \\
\hline $\begin{array}{l}\text { 6-Little experience } \\
\text { in preparing these } \\
\text { traditional food }\end{array}$ & 22 & 34 & 36 & 24 & 34 & 2.91 & 1.373 & 58.13 \\
\hline & 389 & 180 & 130 & 99 & 102 & 3.74 & 1.328 & 74.77 \\
\hline
\end{tabular}

$\mathrm{S} . \mathrm{D}=$ standard deviation, $\mathrm{M}=$ mean, $\mathrm{P}=$ percentage, $\mathrm{R}=$ Ranking

The results in table 6 revealed that the grand mean of the most important challenges of serving traditional food is (3.74), from a Likert scale (1 strongly disagree, 2 disagree, 3 neutral, 4 agree and 5 strongly agree) and this value is more close to 'sometimes' option, and according to the table (6) the percentages of all steps was Lack of good marketing for these food (84.08\%) Globalization and proliferation of fast food(81.6\%) The guests does not know about the traditional food (76.27\%) Consumers fear the use of this type of food (76.13\%) Some customers believe that these food are not healthy (72.4\%) and Little experience in preparing these traditional food $(58.13 \%)$ and this result agree with Weichselbaum et al, (2009) and UNWTO(2012) .

Table (7): Factors Help in The Spread of Traditional Food

\begin{tabular}{|l|c|c|c|c|c|c|c|c|}
\hline \multicolumn{1}{|c|}{ Factors } & $\begin{array}{c}\text { strongly } \\
\text { agree }\end{array}$ & agree & neutral & disagree & $\begin{array}{c}\text { strongly } \\
\text { disagree }\end{array}$ & M & Std & P \\
\hline 1-Food flavor & 89 & 37 & 9 & 6 & 9 & 4.27 & 1.135 & 85.47 \\
\hline $\begin{array}{l}\text { 2-Traditional } \\
\text { food appearance }\end{array}$ & 95 & 28 & 18 & 3 & 6 & 4.35 & 1.037 & 87.07 \\
\hline $\begin{array}{l}\text { 3-Diversiy in } \\
\text { traditional } \\
\text { varieties }\end{array}$ & 86 & 37 & 15 & 6 & 6 & 4.27 & 1.061 & 85.47 \\
\hline
\end{tabular}


International Journal of Heritage, Tourism and Hospitality Vol. (13), No. (2), September, 2019 By: Faculty of Tourism and Hotels, Fayoum University

\begin{tabular}{|l|c|c|c|c|c|c|c|c|}
\hline \multicolumn{1}{|c|}{ Factors } & $\begin{array}{c}\text { strongly } \\
\text { agree }\end{array}$ & agree & neutral & disagree & $\begin{array}{c}\text { strongly } \\
\text { disagree }\end{array}$ & M & Std & P \\
\hline $\begin{array}{l}\text { 4-A new } \\
\text { experience for } \\
\text { tourists }\end{array}$ & 38 & 82 & 12 & 9 & 9 & 3.87 & 1.051 & 77.47 \\
\hline & 308 & 184 & 54 & 24 & 30 & 4.19 & 1.071 & 83.87 \\
\hline
\end{tabular}

$\mathrm{S} . \mathrm{D}=$ standard deviation, $\mathrm{M}=$ mean, $\mathrm{P}=$ percentage, $\mathrm{R}=$ Ranking

The results revealed as shown in table (7) that the overall average of factors help in the spread of traditional food variable is (4.19), from a Likert scale (1 strongly disagree, 2 disagree, 3 neutral, 4 agree and 5 strongly agree) and this value is more close to 'seldom' option, and standard deviation is 1.071. Traditional food appearance (87.07\%) Food flavor (85.47\%) Diversiy in traditional varieties $(85.47 \%)$ A new experience for tourists $(77.47 \%)$ and this result agree whit Sriwongrat, (2008) Trichopoulou et al, (2007), Namkung and Jang, (2007).

Table (8) Factors Affect the Spread of Traditional Food in Luxor

\begin{tabular}{|c|c|c|c|c|c|c|c|c|c|}
\hline \multirow{5}{*}{$\begin{array}{l}\text { External } \\
\text { factors }\end{array}$} & Items & 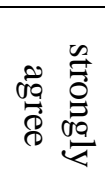 & 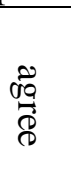 & 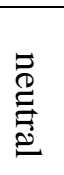 & 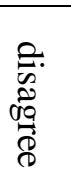 & 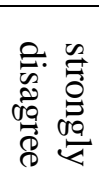 & $\mathrm{M}$ & Std & $\mathrm{P}$ \\
\hline & $\begin{array}{l}\text { 1-Not flourishing style } \\
\text { of tourist foods }\end{array}$ & 66 & 49 & 14 & 9 & 12 & 3.99 & 1.226 & 79.7 \\
\hline & $\begin{array}{l}\text { 2-Not to focus on this } \\
\text { type of food and show } \\
\text { it in scientific research } \\
\text { and show benefits }\end{array}$ & 51 & 43 & 35 & 9 & 12 & 3.75 & 1.216 & 74.9 \\
\hline & $\begin{array}{l}\text { 3-Do not set up } \\
\text { festivals for food }\end{array}$ & 60 & 47 & 22 & 12 & 9 & 3.91 & 1.187 & 78.2 \\
\hline & $\begin{array}{l}\text { 4-Some guests are } \\
\text { concerned about the } \\
\text { use of these types of } \\
\text { food }\end{array}$ & 40 & 45 & 31 & 18 & 16 & 3.5 & 1.294 & 70 \\
\hline \multirow{4}{*}{$\begin{array}{l}\text { Challenges } \\
\text { Work and } \\
\text { employee } \\
\text { skills }\end{array}$} & $\begin{array}{l}\text { 1-Lack of interest by } \\
\text { management in these } \\
\text { types of food }\end{array}$ & 35 & 56 & 16 & 15 & 28 & 3.37 & 1.426 & 67.3 \\
\hline & $\begin{array}{l}\text { 2-Need special } \\
\text { equipment and } \\
\text { resources }\end{array}$ & 21 & 26 & 35 & 37 & 30 & 2.84 & 1.376 & 56.8 \\
\hline & $\begin{array}{l}\text { 3-The stage of } \\
\text { manufacturing are } \\
\text { many and complex }\end{array}$ & 15 & 31 & 39 & 38 & 27 & 2.79 & 1.244 & 55.8 \\
\hline & $\begin{array}{l}\text { 4-Availability of } \\
\text { standard specifications }\end{array}$ & 16 & 37 & 43 & 36 & 18 & 2.98 & 1.184 & 59.6 \\
\hline Marketing & $\begin{array}{l}\text { 1.Lack of marketing } \\
\text { programs specialized } \\
\text { for traditional food }\end{array}$ & 85 & 31 & 9 & 16 & 9 & 4.11 & 1.261 & 82.2 \\
\hline
\end{tabular}


International Journal of Heritage, Tourism and Hospitality Vol. (13), No. (2), September, 2019 By: Faculty of Tourism and Hotels, Fayoum University

\begin{tabular}{|c|c|c|c|c|c|c|c|c|c|}
\hline \multirow[t]{4}{*}{$\begin{array}{l}\text { External } \\
\text { factors }\end{array}$} & Items & 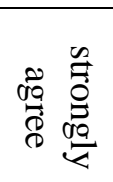 & 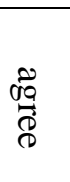 & 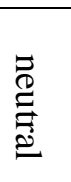 & 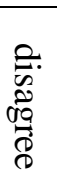 & 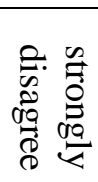 & $\mathrm{M}$ & Std & $\mathrm{P}$ \\
\hline & $\begin{array}{l}\text { 2. No external festivals } \\
\text { to market these foods }\end{array}$ & 86 & 19 & 33 & 6 & 6 & 4.15 & 1.14 & 83.0 \\
\hline & $\begin{array}{l}\text { 3.Web design special } \\
\text { for tourism food }\end{array}$ & 35 & 71 & 25 & 10 & 9 & 3.75 & 1.074 & 75.0 \\
\hline & $\begin{array}{l}\text { 4.Formalization tours } \\
\text { for journalists } \\
\text { organized by food } \\
\text { festivals }\end{array}$ & 56 & 31 & 45 & 6 & 12 & 3.75 & 1.226 & 75.0 \\
\hline
\end{tabular}

We asked the respondents about the challenges that face them to serve the traditional food as shown in table (8) that the types of challenges (challenges related to External factors, challenges related to Work and employee skills and challenges related to Marketing the mean was more than the value 3 from a Likert scale( 1 strongly disagree, 2disagree, 3 neutral, 4 agree and 5 strongly agree) for all Challenges, which refers that respondents approve of all challenges with varying degrees, the result on table (9) pointed out that the respondents gave the challenges related to External factors with higher percentages as the most challenges they face and the reasons by percentages as follow: (Not flourishing style of tourist foods $79.73 \%$, Do not set up festivals for food $78.72 \%$, Not to focus on this type of food and show it in scientific research and show its benefits $74.93 \%$, Some guests are concerned about the use of these types of food $70 \%$ ) also the respondents gave the reasons of challenge related to Work and employee skills this percentage( Lack of interest by management in these types of food $67.33 \%$, Availability of standard specifications 59.6\% Need special equipment and resources $56.8 \%$, The stage of manufacturing are many and complex 55.87\%) And the result also pointed out that the challenges related to Marketing itself percentages is (No external festivals to market these foods $83.07 \%$, Lack of marketing programs specialized for traditional food $82.27 \%$, Web design special for tourism food $75.07 \%$, Formalization tours for journalists organized by food festivals 75.07\%). These results agreed with (UNWTO,2012).

\section{Summary}

Egypt has a long tradition of food production as well as tourism and hospitality. These two industries must link together for the overall economic benefit of the country. Food produced must not endanger consumer health through chemical, biological, or other contaminants and it must be presented honestly. Travelers' diarrhea, the number one illness in tourists, can be caused by viruses, bacteria, or parasites, which can contaminate food or water. The primary aim of this study is to study the effective factors on the spread of traditional food in the tourism areas at Luxor and the scope for creating linkages between tourism and traditional food is evaluated and collected from tow questionnaires completed by (7 Food\&beverage managers 7 assets food\&beverage managers 7 restaurant managers 7 kitchen managers 7 chef steward, $\{19-20$ supervisors $\})(n=170)$. And guests $(n=500)$ in five-star hotels in Luxor. Studying the effective Factors on the spread of Traditional Food in the tourism areas at Luxor and the awareness of responsible for these factors was analyzed and discussed in order to estimate the effective level of this factor.

The main findings of this study were: 
The results indicated that the majority $(95.87 \%)$ of respondent have awareness of traditional food definition.

The respondents indicated they served traditional food like (moulkhia 92.36\% - weka 91.67\% shiesh kebab $86.81 \%$ kebab halla $86.11 \%$ - rise khalta $84.72 \%$ - aish shames $77.08 \%$ - fool medamis $77.08 \%$ - tamia $68.06 \%$ - besara $67.36 \%$ - fata $63.19 \%$ - koushary $62.5 \%$ - thikhna $31.25 \%$ )

The result appears that the It helps to identify peoples customs and cultures $86.4 \%$ Help to use local agricultural products $83.87 \%$ - traditional food effect positively and It is considered an attraction tool (76.93\%) - Offers a new hotel product $76.8 \%$ Increases the market share of the hotel $71.33 \%$ - Contributes to increasing the number of tourists $64.93 \%$

The results revealed important challenges of traditional food is the guests does not know about the traditional food $76.27 \%$ Consumers fear the use of this type of food $76.13 \%$ Lack of good marketing for these food $84.08 \%$ Globalization and proliferation of fast food $81.6 \%$ Some customers believe that these food are not healthy $72.4 \%$ Little experience in preparing these traditional food $58.13 \%$

The results revealed the factors help in the spread of traditional food, traditional food from $87.07 \%$ - Food flavor $85.47 \%$ - Diversiy in traditional varieties $85.47 \%$ - A new experience for tourists $77.47 \%$

\section{Recommendation}

The researcher suggests a set of recommendations based on the study as follow:

Recommendation for hotels:

Taking into consideration the important contribution of foods and beverages in the tourist activity, incorporation of some of the traditional food items is a good idea for the hospitality industry in Egypt.

Due to the changes of Egyptians lifestyle which made the catering services are more important, need to be considered in menu design as Egyptian taste

3-Should consider the following dishes can be selected to incorporate in hotel catering as they get better preference:

Malaz

Lamb Kebab

Assorted pastry

Koufta

Shawerma

Kouchary

Stuffed Vegetables

Beraam Ruzz

Tamia

Feteer bel laban

Couscous and Vegetables

Sayadeyet el-samak

Nifa

Hommous el Sham

Feter Mishaltet

Recommendation the ministry of tourism:

Can be selected to incorporate in hotel catering.

Investigated food item is suitable to be served in every catering active Caterers and professional should not depend on their feelings and personal preference and should use the marketing tools on a scientific Basis to investigate the needs and wants of their customers.

A knowledge about the long history of Egyptian culture may be considered in creating a special atmosphere and menus as the research Declares that more knowledge improves the feedback of customers. 
Egyptian culinary education should be considered in training programs for both management and food beverage staff-Incorporation of Egyptian traditional foods in hotel catering would considerably support and help The recognition of Egyptian cuisine in the field of hospitality Serving Egyptian foods and beverages would be adopted through the Features, culture, and atmosphere characteristic to the original condition the required modifications on the used items should be accomplished in order to produce dishes having high palatability and high hygienic quality-Original recipes need to be documented and developed to have standard dishes and ready to meet the international requirements the hospitality need.

\section{References}

Boniface, P. (2003). Tasting tourism: Travelling for food and drink. Hampshire: Ashgate Publishing Limited.

Cetin, G., \& Bilgihan, A. (2015). Components of cultural tourists' experiences in destinations. Current Issues in Tourism. Ahead of print. doi:10.1080/13683500.2014.994559.

Eastham, J. F. (2003). Valorising through tourism in rural areas: moving towards regional partnerships. In C. M. Hall (Ed.), Food Tourism Around the World: Development, management, and markets. Oxford, UK: Butterworth-Heinemann.

Ebster, c. \& Guist, i. M. A. (2005). The role of authenticity in ethnic theme restaurants. Journal of foodservice business research, 7, 41-52

Fathimath, A. (2009) .The Role of Local Food in Maldives Tourism: A Focus on Promotion and Economic Development. Master of Philosophy (MPhil) in Tourism University of Technology. Tourism Research Institute (NZTRI) New Zealand urce

Fields, K. (2002). Demand for the gastronomy tourism product: motivational factors. In A.-M. a. G. R. Hjalager (Ed.), Tourism and gastronomy (pp. 36-50). London:

Gall, F. (2018). A volume in Woodhead Publishing Series in Food Science, Technology and Nutrition 2018, Pages 3-24.

Guerrero, L., Guàrdia, M. D., Xicola, J., Verbeke, W., Vanhonacker, F., Zakowska-Biemans, S., Hersleth, M. (2009). Consumer-driven definition of traditional food products and innovation in traditional foods. Aqualitative cross-cultural study. [doi: I: 10.1016/j.appet.2008.11.008]. Appetite, 52(2), 345-354.

Hall, C. M., \& Sharples, L. (2003). Consuming places: The role of food, wine, and tourism in regional development. In C. M. Hall, L. Sharples, R. Mitchell, N. Macionis \& B. Cambourne (Eds.), Food Tourism Around the World: Development, Management, and Markets (pp. 2559). Oxford, UK: Butterworth- Heinemann.

Jalis, H., Che, D., Markwell, K. (2014). Procedia - Social and Behavioral Sciences: Utilising Local Cuisine to Market Malaysia as a Tourist Destination pp102-110

Jones, A., \& Jenkins, I. (2002). 'A taste of Wales - Blas Ar Gymru': Institutional malaise in promoting Welsh food tourism products. In A.-M. Hjalagar \& G. Richards (Eds.), Tourism and Gastronomy (pp. 114-131). Oxon, UK: Routledge.

Kim, S., Lee, C., Klenosky, B. (2003). The influence of push and pull factors at Korean national parks. Tourism Management, 24, 169-180.

Kivela, J., Crotts, J.C. (2006). Tourism \& gastronomy: Gastronomy's influence on how tourist experience a destination. Journal of Hospitality and Tourism Research, 30, 354-377.

Liu, y. \& jang, s. (2009). Perceptions of Chinese restaurants in us: what affects customer satisfaction and behavioral intentions? International journal of hospitality management, 28, 338-348. 
Mak, A.H.N., Lumbers, M., Eves, A., Chang, R.C.Y. (2012). Factors influencing tourist food consumption. International Journal of Hospitality Management, 31, 928-936

Namkung, y. \& Jang, s. (2007). Does food quality really matter in restaurants? Its impact on customer satisfaction and behavioral intentions. Journal of hospitality and tourism research, 31, 387-410.

Pilcher, J. M. (2006). Food in world history. Oxon: Routledge

Quan, S., Wang, N. (2004). Towards a structural model of the tourist experience: an illustration from food experiences in tourism. Tourism Management, 25, 297-307.

Ryu, K., Jang, S. (2006). Intention to experience local cuisine in a travel destination: the modified theory of reasonable action. Journal of Tourism and Hospitality Research, 30, 507516.

Santich, B. (2007). Hospitality and gastronomy: Natural allies. In C. Lashley, P. Lynch \& A. Morrison (Eds.), Hospitality: A social lens (1 ed.). Oxford, UK: Elsevier.

Selwood, J. (2003). The lure of food: food as an attraction in destination marketing I Manitoba, Canada. In C. M. Hall, L. Sharples, R. Mitchell, N. Macionis \& B. Cambourne (Eds.), Food tourism around the world: Development, management, and markets (pp. 178-191). Oxford: Butterworth-Heinemann.

Sharma, K. (2005). Tourism and entrepreneurship. In Author (Ed.), Tourism and development (pp. 192-206). New Delhi, India: Sarup \& Sons.

Sriwongrat, c. (2008). Consumers' choice factors of an upscale ethnic restaurant. Msc, Lincoln university.

Sulek, j. M. \& hensley, r. L. (2004). The relative importance of food, atmosphere, and fairness of wait: the case of a full-service restaurant. Cornell hotel and restaurant administration quarterly, 45, 235-247.

Tannahill, R. (2002). Food in history. London: Headline Book Publishing

Tao, T. C. H., \& Wall, G. (2009). A livelihood approach to sustainability. Asia Pacific Journal of Tourism Research, 14(2), 137-152.

Telfer, D.J., Wall, G. (2000). Strengthening backward economic linkages: local food purchasing by three Indonesian hotels. Tourism Geographies, 2, 421-447.

Trichopoulou A, Soukara S, Vasilopoulou E (2007) Traditional foods: a science and society perspective. Trends in Food Science \& Technology 18:420-427.

Trichopoulou A, Vasilopoulou E, Georga K, Soukara S, Dilis V (2006) Traditional foods: Why and how to sustain them. Trends in Food Science Technology 17:498-504.

UNWTO, World Tourism Organization (2012), Global Report on Food Tourism, Madrid Food Inform EuropeReso W World Tourism http://www.unwto.org/pub/rights.htm

Vanhonacker F, Verbeke W, Lengard V. (2008) Consumer-based definition and general image of traditional foods in Europe. In:

Perspectives of Traditional Food Supply Chains on the European Market, Proceedings of12th Congress of the European Association of Agricultural Economists 'People, Food and Environments: Global Trends and European Strategies', 26-29 August 2008, Ghent, Belgium.

Verbeke, W. (2011) Consumers' expectations towards traditional food, FOCUS-BALKANS 2nd OPEN SEMINAR FOCUS on FOOD

Weichselbaum E, Benelam B, Costa HS (2009). Traditional Foods in Europe-6th Synthesis ReportEUROFIR.http://www.eurofir.net 